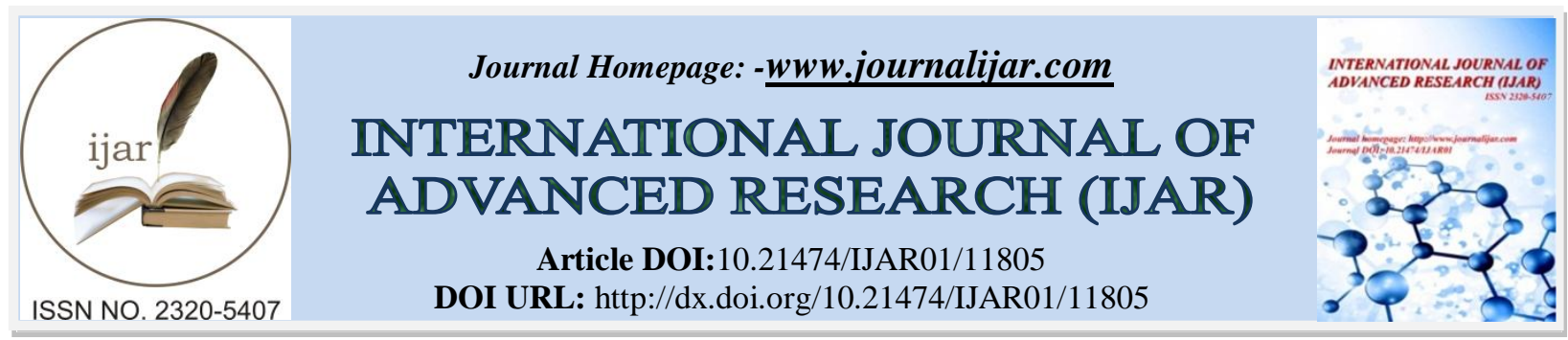

RESEARCH ARTICLE

\title{
THE INFLUENCE OF ECONOMIC AND SOCIAL FACTORS ON MIGRATION MANAGEMENT IN EU COUNTRIES
}

Oana Vasile

PhD Candidate, Bucharest University of Economic Studies, Romania.

\section{Manuscript Info}

Manuscript History

Received: 26 July 2020

Final Accepted: 31 August 2020

Published: September 2020

\begin{abstract}
As the 21st century globalization, it has become more clear that the evolution of the migration phenomenon will bring drastic changes in the population structure and the appurtenance to a multi-ethnic society will become the social rule. In this context, the relation between the migration decision and the social and economic factors of the origin or destination countries becomes a strategic one. In order to optimize the positive effects of migration, the policies of the specific economic and social fields need to be harmonized with the migration strategies at national and EU level. The article focuses on the influence of the social and economic factors on the migration management at EU level using quantitative research methods. The research results indicated that the main economic and social factors that greatly influence migration management are the manner in which the labour market functions, and in particular its demographic and competitive deficiencies. Scientists, specialists from the competent public authorities can capitalize the results obtained, improving policies and strategies in this field in view of the benefit of the local community and of migrants who want to integrate in the community.

Copy Right, IJAR, 2020,. All rights reserved.
\end{abstract}

\section{Introduction:-}

Human mobility is a long-standing feature of global history, where cross-border travelling and increasing social diversity occur as inevitable phenomena. People often see migration as a recent phenomenon. However, migration has been a feature of human existence for centuries (Julia et al., 2019). People have always migrated, in groups or individually, to find new economic opportunities, to flee religious intolerance or political repression, or even to trade and travel to new places (McDowell, L., Anitha, S. and Pearson, 2017).

As the $21^{\text {st }}$ century progresses, it has become clear that the evolution of the migration phenomenon will bring about drastic changes in the population structure, and living in a multi-ethnic society with a high degree of mobility will become the social rule. Therefore, the role of institutional, social and academic players working in the field of migration has been to manage this phenomenon and prepare future generations for this new stage, by advocating understanding of the underlying causes of migration, eradicating racial, religious and cultural fears and misconceptions, encouraging people to have a positive perspective on the effects of migration and developing tolerance in interpersonal relationships (Natter, 2018) .

The social crisis that erupted in 2015, with the exodus of asylum seekers from Syria to Europe, brought the phenomenon of migration back to everyone's attention. Media reports, sometimes exaggerated and obviously 
manipulative, complemented by the right-wing political discourse of the rising populist parties at the time, have helped induce into the social collective negative perceptions and stereotypes about migration in general (Collett, 2013). One could notice a major lack of communication coming from the authorised public institutions, a clear split in the relationship between the main players involved in migration management and an inability to provide answers to the deepening crisis.

\section{Literature Review:-}

The economic and social aspects of migration have always been a topic of interest, both for academia and for specialists or practitioners, even more so in the context of developing new migration strategies in the European Union (Bonjour and Chauvin, 2018)(Simpson, 2017)(De Haas, 2011). Migration is influenced by a combination of economic, political, social and environmental factors: either in the country of origin of a migrant (impulse factors) or in the country of destination (attraction factors) (Trauner, 2016). Historically, relative economic prosperity and political stability in the EU are considered to have had a significant attraction effect on immigrants in the context of the 2015 crisis. Depending on the economic or social motivations behind the decision to migrate, migrants are divided into three categories (Grzymala-Kazlowska and Phillimore, 2018):

1. Migrants in search of economic opportunities in the country of destination;

2. Migrants who go abroad in order to accumulate savings or human capital, so that when they return to their country of origin they can benefit from increased economic opportunities;

3. Migrants who are determined to leave their country of origin due to military, political, ethnic or religious repression.

In general, the decision pertaining to migration can be made by individuals or families (Bakker, Cheung and Phillimore, 2016). The reasons why migrants choose to leave their home country are varied, and the factors that help them decide whether or not to leave their country of origin are political, social or ethnic in nature. But the highest impact in making this decision pertains to the economic factors and especially the difference in salaries in the country of origin compared to the potential country of destination. The prospect of a better salary in the country of destination positively influences a migrant's decision to go to said country. This is also closely linked to improving the quality of life of migrants and their families. Ultimately, a significantly better salary than the one obtained in the home country is meant to provide both safety and security, better education for children, access to better health systems, and personal and professional development. Even if the pay gap from one country to another has a great impact in the decision to leave one's home country, the migrant also takes into account a number of political and social factors, such as respect for human rights and the rule of law and freedom (Vasile and Androniceanu, 2018b) $\mathrm{V}$ (Vasile and Androniceanu, 2018a).

According to new theories of international migration, the decision of a family member to migrate may, in fact, be a "collective" one, since the family shall be joining the migrant. This is an instance of family reunification or resuming relationships with friends. Unlike the factors that determine migration at an individual level, the decision of the entire family to migrate is only partially generated by the socioeconomic motivations of the migrants themselves (Crawley and Hagen-Zanker, 2018), rather having more to do with the opportunities and restrictions all members of said family face.

At present, there is no unitary and coherent theory of international migration, but there are different theories that have developed, most often, in isolation from each other (Massey et al., 1993)(Massey, Durand and Malone, 2005). Managing the current trends and evolutions of migratory flows need an understanding of migration as a dynamic process, with influences generating from the economic, social, cultural or political area (Lambert, 2017).

\section{The purpose of the research:}

The article aims to analyse how economic and social factors influence the phenomenon of migration in EU member states. The results regarding the need to correlate public policies in the economic, social and migration fields, can contribute to the efficiency of migration management as a whole and to a comprehensive understanding of the phenomenon. Scientists, specialists from the competent public authorities can capitalize the results obtained, improving policies and strategies in this field in view of the benefit of the local community and that of migrants who want to integrate in said community. 


\section{Research methods:-}

This study uses a quantitative approach in terms of the research methods used. A questionnaire with single-answer matrix questions on each row was used to collect the data, which offered the possibility to measure several aspects according to pre-established criteria $(1=$ none; $2=$ to a small extent; $3=$ moderately; $4=$ to a large extent; $5=$ completely). The number of respondents was set at the level of relevant players from EU member states, nongovernmental organizations, public authorities, agencies of the European institutions. In total, there were 47 questionnaires completed online, of which $89 \%$ pertained to people with top or middle management coordination positions and $11 \%$ pertaining to people with execution positions.

In order to complete the data obtained with the help of the questionnaire and to cover a large geographical and temporal area with a low cost, we also used the method of document analysis, using the following data collection sources:

\section{Official documents:}

programmatic documents prepared by the European Union institutions (directives, strategies, communications, studies aimed at presenting the evolution of the phenomenon in the Member States), national legislation, activity reports, articles and press releases published on the official websites of the institutions with jurisdiction in the field.

\section{Statistical data:}

articles and studies containing statistical data presented by EUROSTAT, statistical data published by the European Commission on the official website, national statistical data published by the National Institute of Statistics;

Secondary data obtained from another research conducted at national and EU level.

In order to verify the results obtained through the above-mentioned methods and to analyse the connection between several economic and social variables we used the statistical correlation, calculating the Pearson correlation coefficient. With respect to the methods related to processing, systematization of data and interpretation of results, statistical and econometric methods developed using the Microsoft Office Excel 2010 program were used.

\section{Presenting and analysing the results of the research:}

The study analysed the following economic indicators: labour shortage, economic growth rate, minimum wage, the degree of absorption of European funds and the system of social taxes and duties.

As it results from the data presented in Fig. 1, at least $63 \%$ of respondents believe that labour shortages greatly influence the migration management system in EU Member States.

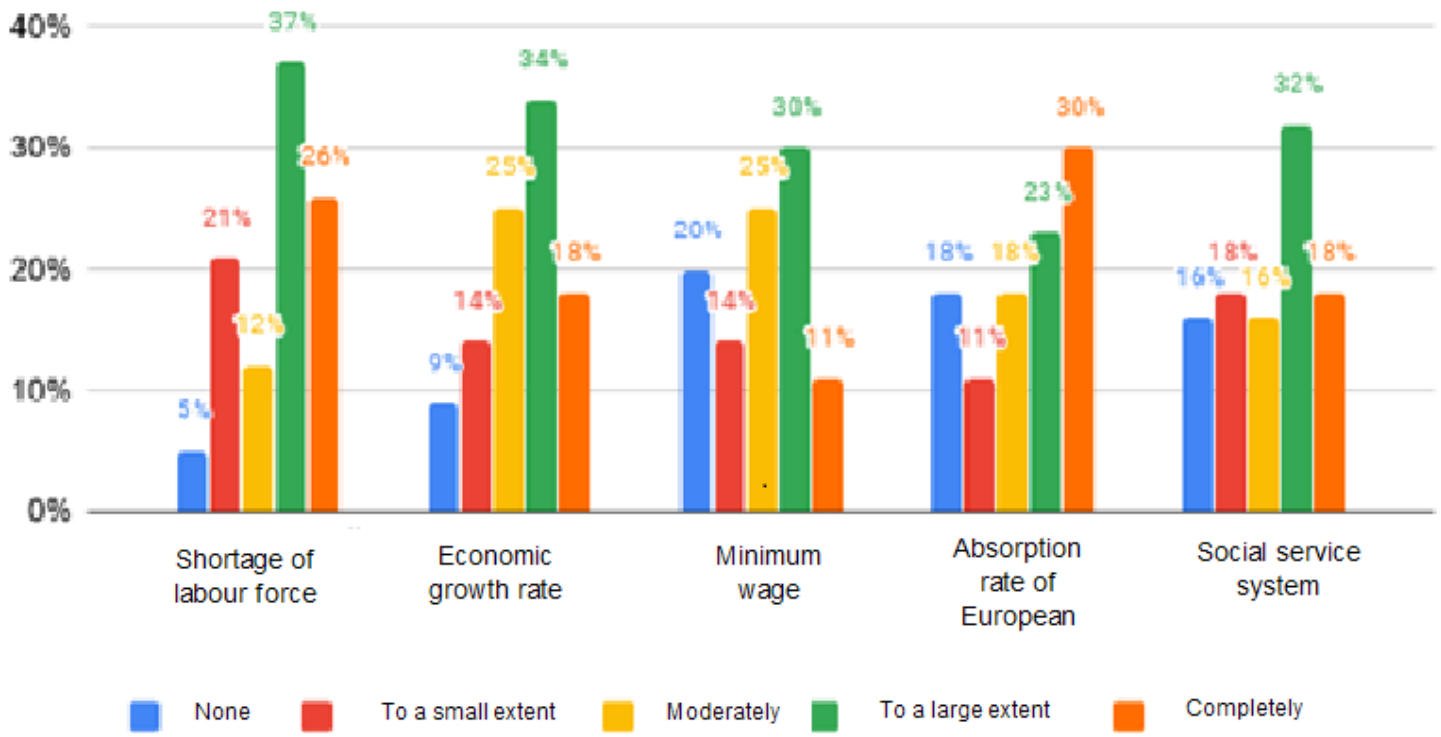

Fig. 6.5:- The influence of economic factors on migration management in the EU. 
In general, the labour shortage is closely linked to the emigration rate in some Member States calculated as a ratio between the number of emigrants and the country's population, respectively: $22.3 \%$ Portugal (2.3 million emigrants), 20.4\% Croatia (0.9 million emigrants), 17.5\% Romania (3.57 million emigrants), 16.5\% Bulgaria (1.3 million emigrants) or 11.5\% Poland (4.7 million emigrants) (Migration Policy Institute, 2020). The gradual transition from temporary to permanent emigration has led, over time, to considerable losses among the population of the Member States. International mobility is higher among people of the right age for employment, thus generating in a high rate of population aging. The decreasing number of available jobs in migrant-exporting Member States has led to a slowdown in economic growth and a decline in economic activity.

In this context, it is necessary for emigration countries to promote national strategies and policies that facilitate the attraction of economically competitive young immigrants, thus alleviating part of the national labour shortage. For example, Romania has, for the first time, introduced in the 2019-2021 National Strategy on Immigration Project, strategic objectives on attracting labour force from third countries. At the same time, the competent Romanian authorities have carried out in these third countries information campaigns for potential migrants who would like to integrate on the Romanian labour market. Thus, the conditions for obtaining a residence permit for work purposes, the conditions that Romanian employers are obliged to provide to workers from third countries and the necessary qualifications for labour-intensive economic sectors were presented.

Another factor that $52 \%$ of respondents considered particularly important for the management of migration is the rate of economic growth. There is a two-way relationship between the growth rate and the migration phenomenon, respectively a higher growth rate can attract migrants in search of economic opportunities, and migration to certain destinations that face a low level of jobs can generate economic growth. Immigration has a beneficial economic impact when immigrants have highly qualified professional skills (Borjas, 2019). Finally, a country wishing to use immigration as a tool for economic growth must consider developing policies to facilitate the issuance of residence permits for highly qualified immigrants (Vasile and Androniceanu, 2016). As the policies and strategies needed to implement the above-mentioned actions involve actions in the fields of migration, employment, social security and education, it is mandatory to develop common procedures and standards to regulate how highly qualified immigrants can be used to their full professional potential on the labour market.

$53 \%$ of respondents considered that the degree of absorption of European funds greatly influences the migration management system. At the level of the European institutions, it is estimated that EU funds represent only a small part of the total expenditure related to migration in the EU and that a much larger part of the amounts needed to manage the phenomenon are provided directly by EU Member States (The European Parliament - Policy Department for Budgetary Affairs and Union, 2018). Over 70\% of the respondents from Romania, Bulgaria, Lithuania, Latvia, Slovenia considered that European funds fully influence the migration management system.

The European funds used for the effective management of migration in Romania represent over $70 \%$ of the total funds used (Vasile and Androniceanu, 2018). The only problem noted by the respondents to the interview is that the functionality of NGOs has become dependent on funds managed by central public authorities, transforming the relationship between these structures into one of subordination and silent acceptance of decisions.

Regarding the social indicators, the study analysed the following variables: population size, emigration rate, ethnic structure of the population, degree of discrimination against immigrants, nationalist and radical structure of the population. 


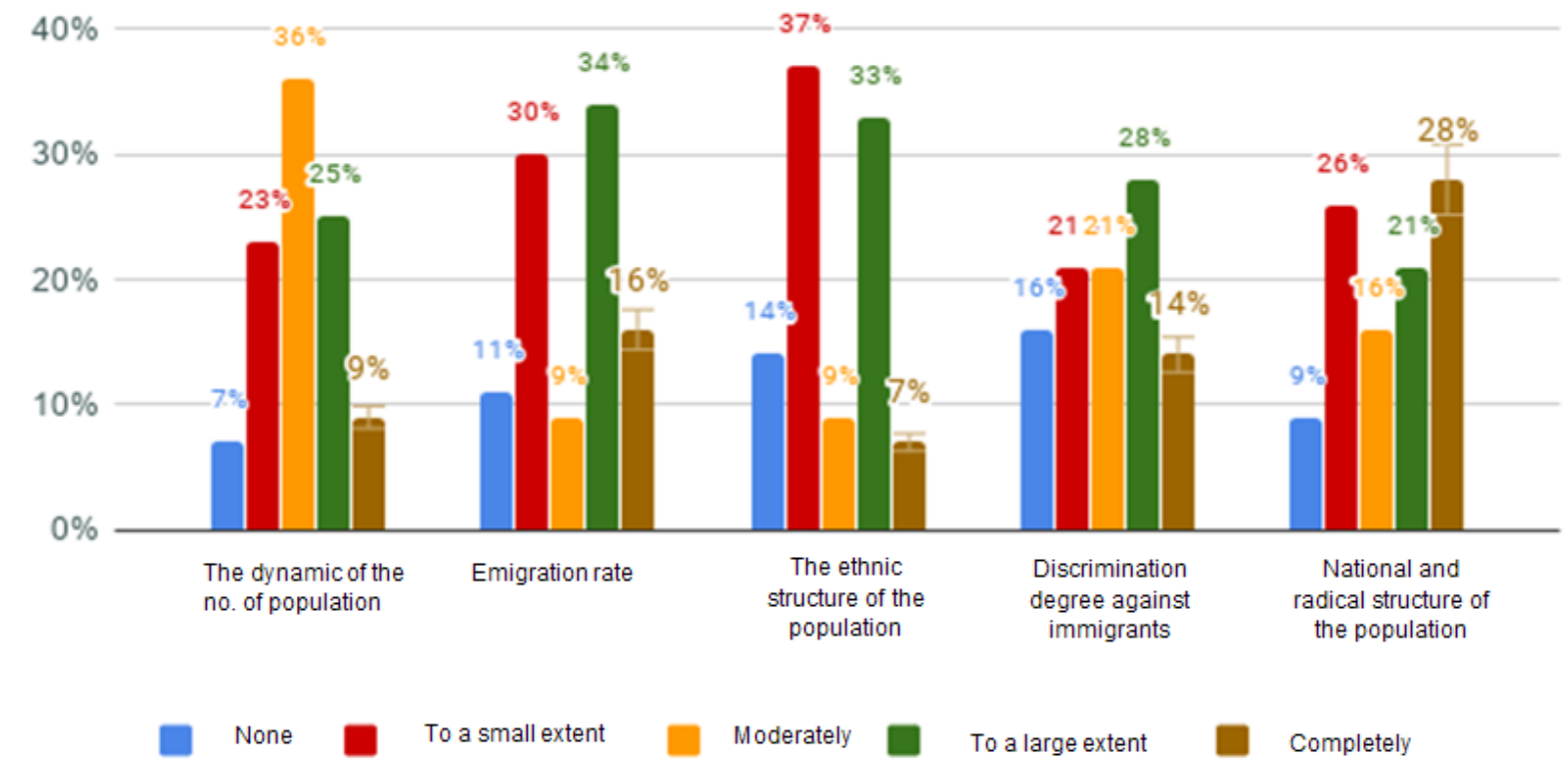

Fig. 6.6:- The influence of social factors on migration management in the EU.

According to the data presented in Fig. 2, 50\% of respondents mentioned that the emigration rate has a significant impact on the way immigration policies and strategies are constructed at national level. The high emigration rate in the Member States is generated by the identification of more advantageous economic and social opportunities in other Member States than in the countries of origin. At the social level, a high emigration rate has, in the medium and long term, serious effects on the structure and dynamics of the population, respectively the decrease of the birth rate, the increase of the aging rate of the population and the increase of the labour deficit. To provide an appropriate response to these problems that may arise over time, national governments can develop policies that support legal migration for work and family reunification purposes.

$65 \%$ of respondents mentioned that the nationalist and radical structure of the population has at least a moderate influence on the migration management system. The rise of nationalism in EU Member States has been fuelled by an anti-immigration political mobilization based on the perceived or projected negative influences that migration can have on national culture. Increasing nationalism at Member State level poses a major challenge for the migration management system, from the perspective of developing social protection and integration policies for migrants in host countries. At the same time, a coherent migration management system should focus on identifying the best means of informing local communities about the benefits of migration. In the absence of adequate information on the advantages and disadvantages of migration, the population will be manipulated by far-right parties and make it impossible for migrants to have a sustainable integration.

The discrimination degree of the population on immigrants was mentioned by $63 \%$ of the respondents as a factor with a moderate influence on the way of managing the migration phenomenon in the EU. Discrimination means the process of treating people differently, negatively and adversely on the grounds of racial or ethnic origin, religion or belief, disability, age and sexual orientation. The right of all people to be equal before the law and be protected against discrimination is a fundamental principle of all democratic societies. However, in the EU, 6 out of 10 people (59\%) believe that discrimination on ethnic grounds is widespread in their country, but that the variations are very high from one Member State to another. There are 17 Member States, where over 50\% of the population considers discrimination to be a widespread phenomenon in their country, the highest percentages being found in the Netherlands (76\%), France (74\%), Belgium $(71 \%)$ and Sweden $(70 \%)$. When it comes to discrimination on the grounds of skin colour, these percentages increase a little in relation to each of the above-mentioned Member State (The European Commission, 2019b).

As it results from Table no. 1, in orderto establish interdependence between the net migration rate per 1000 inhabitants and various quantitative economic variables (GDP growth rate per capita, employment rate of the population aged 18-64, unemployment rate for the population aged 15-24) and social (poverty and social exclusion 
rate, the rate of people over 65 in the population and the life expectancy of the population), we used the method of statistical correlation for Romania. We considered the variable "net migration rate" relevant, taking into account the fact that the respondents to the questionnaires considered that it greatly influences the migration management both from an economic and social point of view.

The net migration rate per 1.000 inhabitants is calculated according to the formula $\mathrm{N}=(\mathrm{I}-\mathrm{E}) / \mathrm{M} \times 1.000$, where $\mathrm{N}$ $=$ the net migration rate; $\mathrm{I}=$ number of immigrants, = number of emigrants; $\mathrm{M}=$ population in the middle of the calendar year.

Table 1:- Percentage / numerical presentation of the variables used for statistical correlation analysis.

\begin{tabular}{|l|l|l|l|l|l|l|l|}
\hline Years & $\begin{array}{l}\text { Net migration } \\
\text { rate per 1.000 } \\
\text { inhabitants } \\
\text { (migrants) }\end{array}$ & $\begin{array}{l}\text { Poverty } \\
\text { and social } \\
\text { exclusion } \\
\text { rate }(\%)\end{array}$ & $\begin{array}{l}\text { GDP } \\
\text { growth rate } \\
\text { per capita } \\
(\%)\end{array}$ & $\begin{array}{l}\text { Minimum } \\
\text { wage } \\
(\text { RON) }\end{array}$ & $\begin{array}{l}\text { Unemployment } \\
\text { rate } \\
\text { population aged } \\
15-24(\%)\end{array}$ & $\begin{array}{l}\text { Rate of } \\
\text { people over } \\
\text { 65 in the } \\
\text { population } \\
(\%)\end{array}$ & $\begin{array}{l}\text { Life } \\
\text { expectancy } \\
\text { of } \\
\text { population } \\
\text { tani) }\end{array}$ \\
\cline { 2 - 8 } & 1 & 2 & 3 & 4 & 6 & 7 & 8 \\
\hline 2007 & $-6,778$ & 47 & $-8,8$ & 440 & $-1,2$ & & 69,9 \\
\hline 2008 & $-7,397$ & 44,2 & $-11,1$ & 540 & $-1,5$ & 15,4 & 69,9 \\
\hline 2009 & $-6,512$ & 43 & $-4,7$ & 600 & $-0,2$ & 16,1 & 70,0 \\
\hline 2010 & $-5,627$ & 41,5 & $-3,3$ & 600 & 2,8 & 16,1 & 70,4 \\
\hline 2011 & $-4,741$ & 40,9 & 2,5 & 670 & 6,3 & 16,1 & 70,8 \\
\hline 2012 & $-3,856$ & 43,2 & 2,5 & 700 & 2,6 & 16,1 & 70,9 \\
\hline 2013 & $-2,971$ & 41,9 & 3,9 & 800 & 1,6 & 16,3 & 71,6 \\
\hline 2014 & $-3,133$ & 40,3 & 3,8 & 900 & 0,1 & 16,5 & 71,3 \\
\hline 2015 & $-3,294$ & 37,4 & 4,4 & 1050 & $-0,9$ & 17 & 71,4 \\
\hline 2016 & $-3,456$ & 38,8 & 5,4 & 1250 & $-3,1$ & 17,4 & 71,7 \\
\hline 2017 & $-3,617$ & 35,7 & 7,7 & 1450 & $-5,7$ & 17,8 & 71,7 \\
\hline 2018 & $-3,779$ & 32,5 & 5,1 & 1900 & $-5,5$ & 18,2 & 71,7 \\
\hline 2019 & $-3,181$ & & & 2080 & $-3,8$ & 18,5 & \\
\hline
\end{tabular}

Source: the data were taken from the official websites of EUROSTAT, United Nations - World Population Prospects and the National Institute of Statistics: https://insse.ro/cms/files/Web_IDD_BD_ro/index.htm, https://ec.europa.eu/eurostat/data/database, https://www.macrotrends.net/countries/ROU/romania/net-migration

In 2007, after Romania's accession to the European Union, free movement in the European space and the desire to improve the quality of life led to an increase in departures from the country, 544.074 people choosing to emigrate temporarily to countries such as Italy and Spain (an emigration rate of $25.7 \%$ ). At the same time, the stability of family relations by their reunification abroad also had an important influence on the migration balance (Iftimoaei and Baciu, 2018). The dynamics of departures remained at high levels during 2007-2011, and after 2012 a linear negative trend was maintained without significant differences from one year to another. The negative values of the net migration rate resulted from the fact that the number of Romanians who emigrated was higher than that of immigrants who chose Romania as their destination country.

The values of the other indicators reflect the fact that the share of people over 65 in the total population has increased, the life expectancy of the population and the employment rate of the active working population has increased, and the number of people at risk of poverty and social exclusion has decreased.

The correlation degree between the net migration rate and the variables mentioned in the table above was calculated using the Pearson correlation coefficient, according to the following formula:

$$
r=\frac{\sum(x-\bar{x})(y-\bar{y})}{\sqrt{\sum(x-\bar{x})^{2} \sum(y-\bar{y})^{2}}}
$$

r: Pearson correlation coefficient, 
x: "net migration rate" variable (column 1 of Table 6.3 )

y: economic and social variables (columns 2-8 of Table 6.3)

In order to calculate the Pearson correlation coefficients, we used the Microsoft Excel Program having as result the correlations types presented in Table 6.4.

Table 6.4:- Results of the correlation between the variables using the Pearson Coefficient.

\begin{tabular}{|c|c|c|c|}
\hline Variable $\mathrm{x}$ & Variable y & $\begin{array}{l}\text { Pearson } \\
\text { Coefficient (r) }\end{array}$ & $\begin{array}{l}\text { The direct relationship between } \\
\text { variables }\end{array}$ \\
\hline $\begin{array}{l}\text { Net migration rate per } 1.000 \\
\text { inhabitants }\end{array}$ & $\begin{array}{l}\text { Poverty and social exclusion } \\
\text { rate }\end{array}$ & $-0,6366254$ & $\begin{array}{l}\text { Reverse correlation between } \\
\text { variables }\end{array}$ \\
\hline $\begin{array}{l}\text { Net migration rate per } .000 \\
\text { inhabitants }\end{array}$ & GDP growth rate per capita & 0,9477442 & $\begin{array}{l}\text { Reverse correlation between } \\
\text { variables }\end{array}$ \\
\hline $\begin{array}{l}\text { Net migration rate per } 1.000 \\
\text { inhabitants }\end{array}$ & Minimum wage & 0,6182849 & $\begin{array}{l}\text { Reverse correlation between } \\
\text { variables }\end{array}$ \\
\hline $\begin{array}{l}\text { Net migration rate per } 1.000 \\
\text { inhabitants }\end{array}$ & $\begin{array}{l}\text { Unemployment rate for the } \\
\text { population aged } 15-24\end{array}$ & $-0,1731072$ & $\begin{array}{l}\text { Reverse correlation between } \\
\text { variables }\end{array}$ \\
\hline $\begin{array}{l}\text { Net migration rate per } 1.000 \\
\text { inhabitants }\end{array}$ & $\begin{array}{l}\text { Rate of people over } 65 \text { in the } \\
\text { total population }\end{array}$ & 0,5013086 & $\begin{array}{l}\text { Moderate correlation between } \\
\text { variables }\end{array}$ \\
\hline $\begin{array}{l}\text { Net migration rate per } 1.000 \\
\text { inhabitants }\end{array}$ & $\begin{array}{l}\text { Life expectancy of the } \\
\text { population }\end{array}$ & 0,9446772 & $\begin{array}{l}\text { High correlation between } \\
\text { variables }\end{array}$ \\
\hline
\end{tabular}

As can be seen from the values presented in Table 6.4, the correlations between the variables are high, moderate and reverse. Given the variety of correlation indices, we cannot determine whether there is a closer link between the net migration rate and economic variables or between the net migration rate and social variables. The highest correlations were established between the Net Migration Rate and the Life Expectancy of the Population $(r=$ 9446772) and between the Net Migration Rate and the GDP Growth Rate per capita $(\mathrm{r}=0.9477442)$.

Real GDP per capita is a macroeconomic indicator that reflects the sum of the market value of all goods and services for final consumption, produced in all branches of the economy within a country within a year, relative to the average population in that year. The online magazine "The Economic Voice" presented in 2017, a study conducted in 31 countries in Europe, the United States and Asia, which confirms that there is a high correlation between the two variables. A high value of GDP per capita will indicate an increased quality of life and a low emigration rate. Therefore, as GDP per capita grows, so will net migration, with a direct link. At the same time, an increased quality of life also generates a higher, variable life expectancy, which is also highly correlated with the net migration rate.

In order to graphically visualize the relationship between the variables that are most related according to the Pearson coefficient, we used the Scatter type graphical representation. We looked at three different types of information that it can give us:

1. if the two series of values are correlated (Correlation);

2. whether the sample on which the measurements were made is homogeneous or heterogeneous (Homogeneity);

3. certain information about the symmetry of the distribution of the two series of values (Symmetry).

In Fig. 3 a strong correlation can be observed between the Net Migration Rate and the GDP Growth Rate per capita, the point cloud having an extremely elongated and thin shape, with a higher point density in the upper right. 


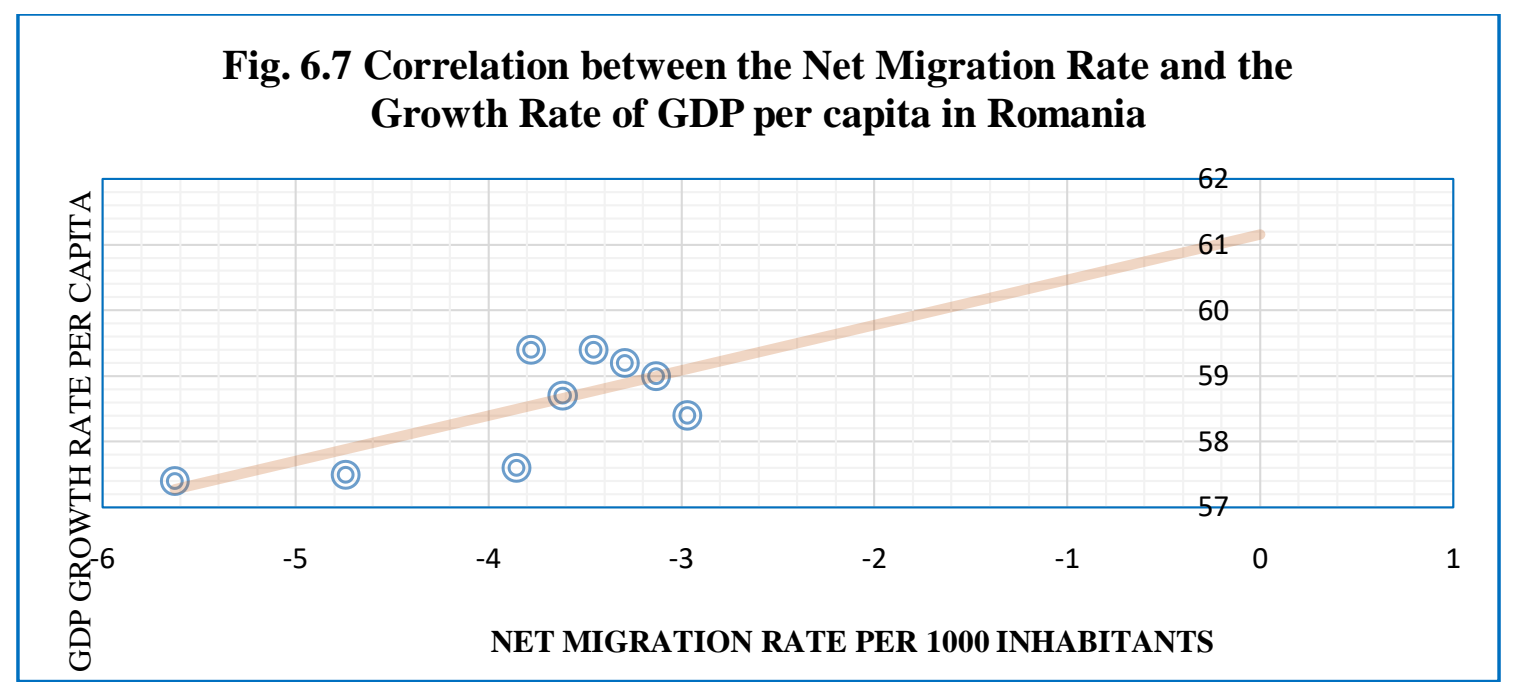

In Fig. 4 a strong correlation can be observed between the variables Net migration rate and Life expectancy of the population, as their values are distributed along a straight line. Also, the sample is homogeneous, which can be seen from the fact that the point cloud does not tend to split into two different clouds. On the other hand, it can be seen that the cloud is denser in the upper right, the values from the Life expectancy of the population series being distributed asymmetrically.

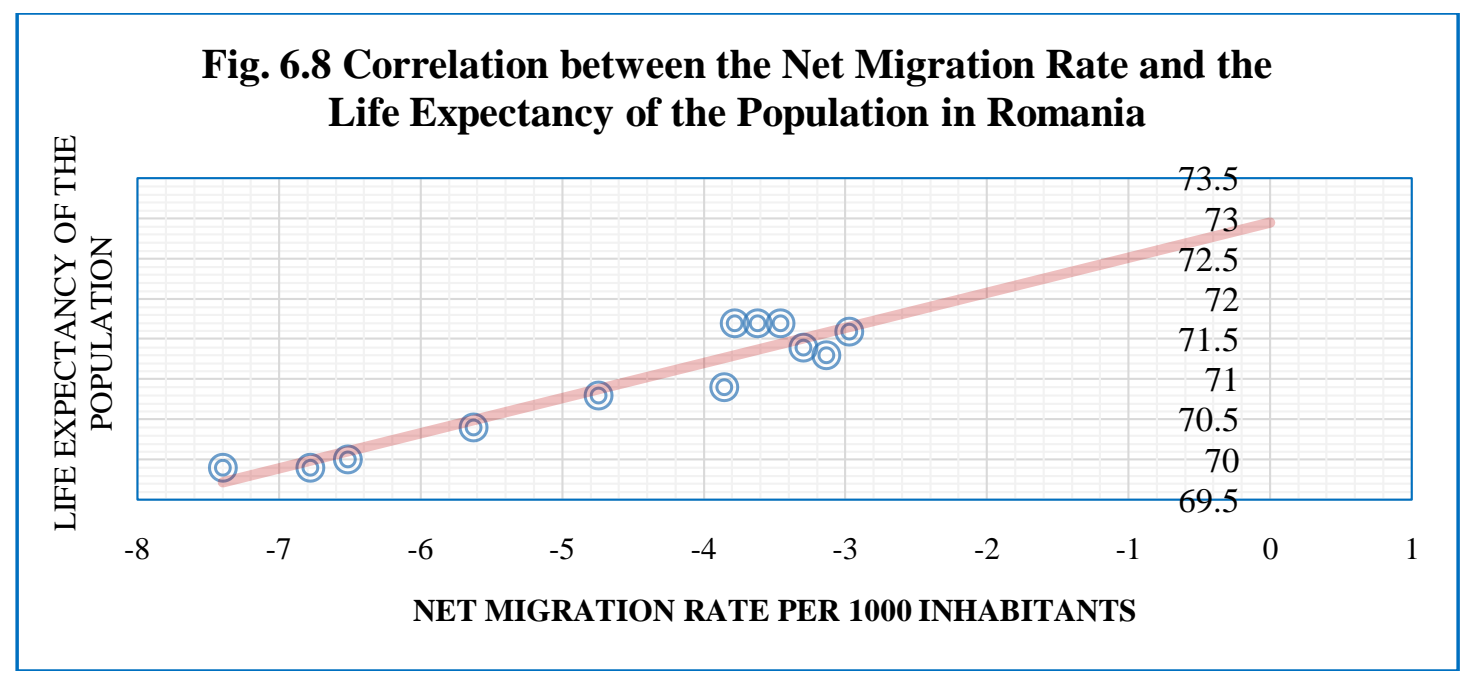

From the analysis of the correlations between the net migration rate and the economic and social variables, it cannot be established whether one of them has a greater or lesser influence on migration management. Therefore, with respect to hypothesis 2, we cannot validate the fact that economic and social factors influence migration management equally, high correlations and low correlations being discovered both in the case of economic and social variables.

\section{Conclusions:-}

The analysis showed that a strategic objective of migration management systems in the EU should be that of harmonizing migration policies in relation to economic, social and political policies and strategies in order to maximize the effects of migration. The research results indicated that the main economic and social factors that greatly influence migration management are the manner in which the labour market functions, and in particular its demographic and competitive deficiencies. 
In view of this, the conclusions generated in this section refer to a number of measures that could help make the decision-making process more flexible, with beneficial effects on both local communities and migrants.

1. promoting national strategies and policies to facilitate the attraction of economically competitive young immigrants, thus alleviating part of the national labour shortage;

2. information campaigns for employers on the stages of the entire recruitment process and on the opportunity of being able to bring in labour force from third countries;

3. making available to employers a package with minimum actions for the integration of newcomers;

4. establishing collaborative relationships between employers and NGOs that can provide migrants with cultural, psychological or health accommodation assistance in European-funded projects;

5. granting temporary job search visas for all categories of migrants;

6. granting short-term visas to highly qualified migrants, which can be converted into work visas provided that they are selected for employment following job interviews;

7. conducting awareness campaigns on the need to import labour force from third countries for the economic development of local communities.

8. countries with high emigration rates from the EU should fund training courses in countries of origin that address identified shortcomings in the labour market;

9. national governments should consider developing policies that facilitate the issuance of residence permits for highly qualified immigrants, recognize and use these qualifications at their true value, while proposing sustainable measures to integrate them into host countries;

\section{References:-}

1. Bakker, L., Cheung, S. Y. and Phillimore, J. (2016) 'The asylum-integration paradox: Comparing asylum support systems and refugee integration in the Netherlands and the UK', International Migration, 54(4), pp. 118-132. doi: 10.1111/imig.12251.

2. Bonjour, S. and Chauvin, S. (2018) 'Social Class, Migration Policy and Migrant Strategies: An Introduction', International Migration, 56(4), pp. 5-18. doi: 10.1111/imig.12469.

3. Collett, B. E. (2013) 'Facing 2020: Developing a New European Agenda for Immigration and Asylum Policy', Policy Brief Series, Migration Policy Institute, (1), pp. 1-8.

4. Crawley, H. and Hagen-Zanker, J. (2018) 'Deciding Where to go: Policies, People and Perceptions Shaping Destination Preferences’, International Migration, p. imig.12537. doi: 10.1111/imig.12537.

5. Grzymala-Kazlowska, A. and Phillimore, J. (2018) 'Introduction: rethinking integration. New perspectives on adaptation and settlement in the era of super-diversity', Journal of Ethnic and Migration Studies. Taylor \& Francis, 44(2), pp. 179-196. doi: 10.1080/1369183X.2017.1341706.

6. De Haas, H. (2011) 'The determinants of international migration. Conceptualizing policy, origin and destination effects', IMI Working Papers Series. Oxford: International Migration Institute, pp. 1-35. doi: imprimé.

7. Julia, Z. et al. (2019) A Big History of Globalization: The Emergence of a Global World System. Springer Nature Switzerland AG.

8. Lambert, H. (2017) 'An Introduction to the Common European Asylum System for Courts and Tribunals: A Judicial Analysis', International Journal of Refugee Law, 29(4), pp. 726-728.

9. Massey, D. S. et al. (1993) 'Theories of International Migration: A Review and Appraisal', Population and Development Review, 19(3), pp. 431-466.

10. Massey, D. S., Durand, J. and Malone, N. J. (2005) 'Principles of operation: Theories of international migration. The new immigration', An interdisciplinary reader, pp. 21-33.

11. McDowell, L., Anitha, S. and Pearson, R. (2017) A History of Migration, Striken Women/Migration. Available at: https://www.striking-women.org/module/migration/history-migration (Accessed: 19 September 2020).

12. Migration Policy Institute (2020) 'Total Immigrants and Emmigrant Populations by Country'.

13. Natter, K. (2018) 'Rethinking immigration policy theory beyond "Western liberal democracies", Comparative Migration Studies. 6(1), p. 4. doi: 10.1186/s40878-018-0071-9.

14. Simpson, N. B. (2017) Demographic and economic determinants of migration, IZA- World of Labor. Available at: https://wol.iza.org/articles/demographic-and-economic-determinants-of-migration/long (Accessed: 28 December 2018).

15. The European Parliament - Policy Department for Budgetary Affairs and Union, D. G. for I. P. of the (2018) EU funds for migration, asylum and integration policies. Available at: https://bruegel.org/wpcontent/uploads/2018/05/EU-funds-for-migration.pdf (Accessed: 7 December 2019).

16. Trauner, F. (2016) 'Asylum policy: the EU's "crises" and the looming policy regime failure', Journal of 
European Integration. Routledge, 38(3), pp. 311-325. doi: 10.1080/07036337.2016.1140756.

17. Vasile, O. and Androniceanu, A. (2016) 'Dynamics of Migration in Romania and Management of Financing Instruments', in The European Proceedings of Social\&Behavioural Sciences. Iasi, Romania: Future Academy.

18. Vasile, O. and Androniceanu, A. (2018a) 'An overview of the Romanian asylum policies', Sustainability, 10(5), p. 1461. doi: https://doi.org/10.3390/su10051461.

19. Vasile, O. and Androniceanu, A. (2018b) 'Strategic Approach to the Immigrants' Problems in Europe', Economics, Management and Financial Markets, 13(3), pp. 34-46. 